\title{
ANALISIS GULIRAN DANA SIMPAN PINJAM KHUSUS PEREMPUAN (SPP) PNPM MANDIRI PERDESAAN DI KECAMATAN SAMATIGA
}

\author{
Triyanto* dan Devie Agustiar ${ }^{* *}$ \\ * Dosen tetap Prodi Ilmu Sosiologi Universitas Teuku Umar \\ ** Dosen Tetap Fakultas Pertanian Universitas Teuku Umar
}

\begin{abstract}
The country's economic growth depends not only on export and industrial output from factories scattered throughout Indonesia. Factories and other large-scale companies only provide macro economic growth, in fact people can not enjoy the growth of the economy directly. Therefore, in order for the people to be prosperous, the State must boost economic growth through micro enterprises run in real terms by the (small) people themselves. In fact, it is difficult for small people to gain access to formal financial institutions to stimulate the growth of micro-enterprises in the community. Finally, the State makes it easy for its people to develop micro businesses managed by the community itself through a program of women's special savings and loans (SPP) PNPM Mandiri Perdesaan. Based on the results of the research shows that this program succeeded in increasing the growth of Micro Enterprises and able to absorb the work force in Kecamatan Samatiga. The SPP-PNPM program is able to generate the creativity of the community in entrepreneurship among the housewives. The SPPPNPM fund roll is used to form the community-run business such as making food and beverage, raising, producing salted fish, and other businesses. Meanwhile, to run the new business is always needed human resources as a manager. Thus, the amount of effort in the community is directly proportional to the needs of the workforce, the SPPPNPM fund spools greatly affect the development of SMEs and labor.
\end{abstract}

Key words: $\quad$ SPP PNPM, Savings and Loans, Samatiga, Aceh Barat.

\section{Pendahuluan}

1.1 Latar Belakang

Ekonomi Indonesia yang terus tumbuh pada tahun 2012 memberikan sinyal yang positif bagi perekonomian negara. Ekonomi negara yang baik semestinya juga berdampak baik terhadap kesejahteraan hidup rakyatnya. Jika pertumbuhan ekonomi yang cukup baik ternyata tidak berdampak pada kesejahteraan rakyat, maka pertumbuhan ekonomi tersebut hanyalah perubahan angka-angka statistik yang tidak bermakna. Pertumbuhan ekonomi terkadang hanya dapat dinikmati segelintir orang yang memang sudah sejahtera, dan semakin menjauhkan orang lainnya dari kondisi sejahtera. 
Kenyataannya sampai saat ini masih banyak rakyat Indonesia yang hidupnya jauh kata sejahtera, atau berada di bawah garis kemiskinan.

Data Badan Pusat Statistik (BPS) yang mengukur kemiskinan menggunakan konsep kemampuan dalam memenuhi kebutuhan dasar, angka kemiskinan di Indonesia mengalami penurunan sebesar 0,13 juta orang $(0,13 \%)$ dari 30,02 juta orang penduduk miskin $(12,49 \%$ dari total penduduk) pada Maret 2010 menjadi 29,89 juta jiwa (12,36 \% dari total penduduk) pada September 2011 dengan garis kemiskinan sebesar Rp 211.726 per kapita perbulan (BPS, 2012). Hal ini disebabkan adanya peningkatan produksi industri manufaktur mikro dan pada Triwulan I sebesar 1,26 persen menjadi 2,21 persen pada Triwulan III.

Kondisi seperti ini menimbulkan dampak tidak adanya kesempatan bagi penduduk miskin untuk mengakses kebutuhan pendidikan, kesehatan, penguasaan teknologi, dan kurangnya keterampilan sebagai konsekuensi kemiskinan. Di Indonesia Usaha Mikro, Kecil dan Menengah (UMKM) memiliki peranan penting terhadap perekonomian nasional terutama sebagai sumber pertumbuhan kesempatan kerja atau pendapatan dan penanggulangan kemiskinan. UMKM mampu menyerap tenaga kerja sebesar 99,40 juta orang pada tahun 2010 99,72 persen tenaga kerja bergerak pada sektor UMKM (Kemenkop, 2011).

UMKM mampu membuktikan ketahanan sebagai landasan perekonomian Indonesia dengan memiliki fleksibilitas yang tinggi dalam menghadapi perubahan kondisi pasar yang cepat baik pada masa krisis ekonomi tahun 1997/1998 maupun tahun 2008. Hal ini dikarenakan UMKM berlandaskan pada pemberdayaan ekonomi lokal sehingga tidak terpengaruh dengan adanya krisis.

Tabel 1. Jumlah Unit Usaha dan Penyerapan Tenaga Kerja Berdasarkan Skala Usaha Tahun 2009 - 2010

\begin{tabular}{|l|r|c|r|r|}
\hline \multirow{2}{*}{ Skala Usaha } & \multicolumn{2}{|c|}{ Tahun 2009 } & \multicolumn{2}{c|}{ Tahun 2010 } \\
\cline { 2 - 5 } & $\begin{array}{c}\text { Unit Usaha } \\
\text { (unit) }\end{array}$ & $\begin{array}{c}\text { Tenaga Kerja } \\
\text { (orang) }\end{array}$ & $\begin{array}{c}\text { Unit Usaha } \\
\text { (unit) }\end{array}$ & $\begin{array}{c}\text { Tenaga Kerja } \\
\text { (orang) }\end{array}$ \\
\hline Usaha Mikro & 52.176 .795 & 90.012 .694 & 53.207 .500 & 93.014 .759 \\
\hline Usaha Kecil & 546.675 & 3.521 .073 & 573.601 & 3.627 .164 \\
\hline Usaha Menengah & 41.133 & 2.677 .565 & 42.631 & 2.759 .852 \\
\hline Total UMKM & 52.764 .603 & 96.211 .332 & 53.823 .732 & 99.401 .775 \\
\hline Usaha Besar & 4.677 & 2.674 .671 & 4.838 & 2.839 .711 \\
\hline
\end{tabular}

Sumber : Kementerian Koperasi dan UMKM 2011 
Jumlah unit UMKM pada tahun 2010 mencapai 53,82 juta unit usaha dan didominasi oleh skala usaha mikro sebesar 98,85 persen yang merupakan usaha rumah tangga, pedagang kaki lima dan jenis usaha mikro lain yang bersifat informal. Pada skala usaha mikro inilah paling banyak menyerap tenaga kerja (pro job) dan mampu menopang peningkatan taraf hidup masyarakat (pro poor). Dengan demikian, adanya perkembangan dan kemajuan UMKM akan sangat membantu dalam mengatasi kemiskinan. Namun yang telah memperoleh kredit perbankan hanya sekitar 37,36 persen atau 19,1 juta unit usaha (Kemenkop, 2011). Salah satu upaya yang dilakukan dalam mengentaskan kemiskinan adalah memberdayakan UMKM melalui akses pembiayaan yang mudah dan tanpa jaminan. Hal ini karena permasalahan utama yang dihadapi UMKM adalah permodalan (Kusmuljono, 2009).

Proses pembangunan berjalan optimal jika berlandaskan pada pemberdayaan masyarakat dengan memperhatikan kesetaraan gender. Hal ini sesuai dengan salah satu tujuan pembangunan milenium (MDGs) di Indonesia yakni mendorong kesetaraan gender dan pemberdayaan perempuan. Pemerintah Indonesia mencanangkan Program Nasional Pemberdayaan Masyarakat (PNPM) Mandiri pada tanggal 30 April 2007 di Kota Palu Sulawesi. PNPM Mandiri ini terdiri dari PNPM Mandiri Perdesaan, PNPM Mandiri Perkotaan dan PNPM Mandiri wilayah khusus dan desa tertinggal. Berdasarkan Kebijakan PNPM Mandiri Perdesaan Tahun 2008, PNPM merupakan salah satu upaya pemerintah untuk mendorong akselerasi penurunan kemiskinan dan pengangguran yang berbasis pemberdayaan masyarakat. PNPM bertujuan meningkatkan kualitas dan kapasitas masyarakat menuju kemandirian dalam pembangunan dengan pelaksanaannya dari, oleh dan untuk rakyat. Alokasi dana Bantuan Langsung Masyarakat (BLM) PNPM 80 persen bersumber dari APBN 20 persen dari APBD.

PNPM Mandiri Perdesaan merupakan program percepatan penanggulangan kemiskinan di perdesaan secara terpadu dan berkelanjutan melalui pemberdayaan masyarakat yang merupakan pengembangan dari Program Pengembangan Kecamatan (PPK) yang telah berlangsung pada tahun 1998 (PNPM Mandiri Perdesaan, 2007). Kegiatan PNPM Mandiri Perdesaan secara besar terbagi dalam lima jenis kegiatan, yaitu kegiatan infrastruktur, pendidikan, kesehatan, Simpan Pinjam kelompok Perempuan (SPP) dan kegiatan peningkatan kapasitas Usaha Ekonomi Produktif (UEP). Salah satu program kegiatan pada PNPM Mandiri Perdesaan yang memberikan fasilitas kredit yang mudah untuk perkembangan UMKM dengan memfokuskan pada pemberdayaan perempuan yaitu program Simpan Pinjam kelompok Perempuan (SPP).

Simpan Pinjam kelompok Perempuan (SPP) merupakan pinjaman modal usaha tanpa agunan dalam bentuk perguliran dengan kegiatan pengelolaan simpanan dan pinjaman melalui pembentukan kelompok 
perempuan. Kegiatan mendapatkan alokasi dana Bantuan Langsung Masyarakat (BLM) kedua terbesar setelah kegiatan infrastruktur yaitu sebesar 960,45 milyar rupiah. Keharusan individu berkelompok dengan individu yang lainnya dalam memperoleh pinjaman SPP menyebabkan terciptanya mekanisme kontrol antara anggota satu dengan anggota lainnya dalam sebuah kelompok. Besarnya pinjaman disesuaikan dengan permintaan yang diajukan dalam proposal. Dalam pelaksanaannya, kegiatan SPP ini tidak boleh hanya kegiatan meminjam, tetapi didalamnya harus ada kegiatan menabung. Hal ini dikarenakan pada dasarnya SPP bertujuan untuk meningkatkan taraf hidup kaum perempuan. Kontribusi perempuan sebagai pelaku Usaha Kecil Menengah (UKM) mencapai 60\% - 80\% jumlah 46 - 49 juta pelaku UKM pada tahun 2008 (BPS,2008).

\subsection{Rumusan Masalah}

Pemerintah Indonesia sudah banyak menjalankan berbagai program dalam memperkuat pendanaan UMKM melalui pemberian kredit untuk mendorong perkembangan UMKM. Namun, masih sedikit skim kredit program pemerintah memfokuskan pada pemberdayaan perempuan. Kelompok usaha di perdesaan pada umumnya merupakan UMKM yang tidak memiliki aset yang cukup dan memiliki status tidak berbadan hukum. Hal inilah yang menyebabkan sulitnya UMKM untuk memperoleh akses kredit perbankan. Oleh karena itu, pemerintah memberikan fasilitas kredit Simpan Pinjam Perempuan (SPP) yang merupakan kegiatan pengembangan ekonomi PNPM Mandiri Perdesaan. SPP merupakan pinjaman yang mudah dan tanpa agunan bagi Rumah Tangga Miskin (RTM) untuk pengembangan usahanya.

SPP memperoleh alokasi dana 25 persen dari total dana BLM dalam PNPM Mandiri Perdesaan. Program Nasional Pemberdayaan Masyarakat (PNPM) Mandiri Perdesaan digulirkan secara Nasional pada April 2007 dan terus dilaksanakan hingga saat ini. Pelaksanaan kegiatan PNPM Mandiri Perdesaan Kabupaten Aceh Barat secara lengkap dapat dijelaskan pada Tabel 2.

Tabel 2: Lokasi dan alokasi Anggaran PNPM Mandiri Perdesaan Aceh Barat

\begin{tabular}{|l|c|c|c|r|r|}
\hline \hline \multirow{2}{*}{ KABUPATEN } & \multicolumn{2}{|c|}{ JUMLAH } & \multicolumn{3}{c|}{ ALOKASI TA 2007 - 2010 } \\
\cline { 2 - 6 } & MUKIM & DESA & APBN & \multicolumn{1}{c|}{ APBD } & \multicolumn{1}{c|}{ JUMLAH } \\
\hline \hline Arongan & 2 & 27 & 5.300 .000 .000 & 3.000 .000 .000 & 8.300 .000 .000 \\
\hline Bubon & 3 & 17 & 6.525 .000 .000 & 2.525 .000 .000 & 9.050 .000 .000 \\
\hline Kaway XVI & 4 & 43 & 7.700 .000 .000 & 3.600 .000 .000 & 11.300 .000 .000 \\
\hline Meureubo & 2 & 26 & 3.210 .000 .000 & 1.990 .000 .000 & 5.200 .000 .000 \\
\hline Pante Ceureumen & 4 & 25 & 5.300 .000 .000 & 3.000 .000 .000 & 8.300 .000 .000 \\
\hline Panton Reu & 1 & 19 & 3.325 .000 .000 & 1.725 .000 .000 & 5.050 .000 .000 \\
\hline Samatiga & 6 & 32 & 2.325 .000 .000 & 1.225 .000 .000 & 3.550 .000 .000 \\
\hline
\end{tabular}




\begin{tabular}{|l|c|c|r|r|r|} 
Sungai Mas & 2 & 18 & 3.325 .000 .000 & 1.725 .000 .000 & 5.050 .000 .000 \\
\hline Woyla & 3 & 43 & 4.900 .000 .000 & 2.900 .000 .000 & 7.800 .000 .000 \\
\hline Woyla Barat & 2 & 24 & 5.525 .000 .000 & 2.275 .000 .000 & 7.800 .000 .000 \\
\hline Woyla Timur & 2 & 26 & 5.525 .000 .000 & 2.275 .000 .000 & 7.800 .000 .000 \\
\hline \multicolumn{1}{|c|}{ TOTAL } & $\mathbf{3 1}$ & $\mathbf{3 0 0}$ & $\mathbf{5 2 . 9 6 0 . 0 0 0 . 0 0 0}$ & $\mathbf{2 6 . 2 4 0 . 0 0 0 . 0 0 0}$ & $\mathbf{7 9 . 2 0 0 . 0 0 0 . 0 0 0}$ \\
\hline \hline
\end{tabular}

Peningkatan alokasi jumlah pinjaman dan kelancaran tingkat pengembalian diharapkan dapat memberikan dampak terhadap perkembangan UMKM. Skim kredit program pemerintah untuk mendorong perkembangan UMKM yang memfokuskan pada pemberdayaan perempuan masih relatif sedikit. Selain itu, adanya kendala yang harus diperbaiki mengenai pemahaman keliru di masyarakat yang memandang SPP sebagai dana pemberian pemerintah seperti halnya Bantuan Langsung Tunai (BLT). Oleh karena itu, ada beberapa permasalahan yang akan dijawab dalam penelitian ini, yaitu :

1. Bagaimana keragaan penyaluran pinjaman bergulir program SPP bagi UMKM di Kecamatan Samatiga?

2. Bagaimana dampak perguliran dana SPP PNPM Mandiri Perdesaan terhadap perkembangan UMKM di Kecamatan Samatiga?

\section{Kerangka Pemikiran}

\subsection{Konsep Kredit}

Kredit berasal dari bahasa Yunani yaitu credere yang berarti kepercayaan. Secara umum memiliki arti kreditur (pihak yang memiliki modal/dana) memberikan kepercayaan (kredit/credere) kepada debitur (pihak yang meminjam dana) untuk mengelola sejumlah dana untuk diputarkan agar dapat menghasilkan. Dengan demikian istilah kredit memiliki arti khusus yaitu meminjamkan uang (Suyatno et.al, 2007). Menurut Undang-Undang Nomor 10 Tahun 1998, kredit adalah penyediaan uang atau tagihan yang dapat dipersamakan dengan itu, berdasarkan persetujuan atau kesepakatan pinjammeminjam antara bank dan pihak lain yang mewajibkan pihak peminjam untuk melunasi hutangnya setelah jangka waktu tertentu dengan jumlah bunga imbalan.

Untung (2000) mengatakan bahwa kredit memiliki empat unsur yaitu kepercayaan, tenggang waktu, tingkat resiko dan objek kredit (uang atau modal). Kepercayaan berarti pemberi kredit yakin bahwa dana yang diberikan kepada penerima kredit akan kembali dalam jangka waktu tertentu di masa yang akan datang. Kredit dalam perekonomian mempunyai fungsi diantaranya untuk meningkatkan daya guna uang, meningkatkan peredaran dan lalu lintas uang, meningkatkan perkembangan usaha dan meningkatkan pemerataan pendapatan. Kredit dapat dibedakan menurut berbagai kriteria, yaitu diantaranya dari segi tujuan penggunaannya dan skala sektor usaha yang dijalani. Berdasarkan tujuan penggunaannya, kredit dikelompokkan menjadi 
tiga yaitu :

1. Kredit konsumtif, yaitu kredit yang diberikan kepada perseorangan untuk membiayai keperluan konsumsi sehari-hari.

2. Kredit produktif, baik kredit investasi maupun kredit modal kerja. Kredit investasi adalah kredit yang ditujukan untuk pembiayaan modal tetap, yaitu peralatan produksi, gedung dan mesin-mesin. Sedangkan kredit modal kerja adalah kredit yang ditujukan untuk pembiayaan kebutuhan dunia usaha akan modal kerja yang berupa persediaan bahan baku, persediaan produk akhir dalam proses produksi.

3. Perpaduan antara kredit konsumtif dan kredit produktif (semi konsumtif dan semi produktif).

Berdasarkan besar-kecilnya skala sektor usaha yang dijalani, kredit dapat dikelompokkan menjadi empat jenis yaitu :

1. Kredit usaha mikro, yaitu kredit yang diberikan kepada nasabah usaha mikro yang dimiliki dan dijalankan dengan plafon kredit maksimal sebesar Rp 50 juta.

2. Kredit usaha kecil, yaitu kredit yang diberikan kepada pengusaha yang digolongkan sebagai pengusaha kecil dengan plafon kredit maksimum sebesar Rp 500 juta.

3. Kredit usaha menengah, yaitu kredit yang diberikan kepada pengusaha skala usaha menengah dengan plafon kredit diatas Rp 500 juta sampai dengan Rp 5 miliar.

4. Kredit usaha besar, yaitu kredit yang diberikan kepada pengusaha yang asetnya lebih besar daripada pengusaha skala menengah.

\subsection{Teori Group Lending}

Kredit berbasis kelompok atau dikenal dengan group lending merupakan pemberian kredit kepada individu-individu yang tergabung dalam sebuah kelompok sehingga dapat memiliki akses terhadap permodalan dalam sebuah program. Program yang dilaksanakan biasanya ditunjukkan bagi masyarakat miskin tidak memiliki agunan untuk memperoleh kredit. Menurut Zeller dan Simtowe (2006) kredit berbasis kelompok ini dibuat untuk individu tetapi semua anggota kelompok bertanggungjawab terhadap pembayaran kredit tersebut (joint liability lending). Berdasarkan kewajiban dan tanggung jawab pinjaman bersama maka setiap anggota yang tidak mengalami kesulitan dapat membantu membayar anggota lain yang mengalami kegagalan bayar (intragroup asuransi). Ukuran keberhasilan program pinjaman kelompok dapat dilihat dari tingkat pengembalian. Manfaat positif yang dapat diperoleh jika menggunakan sistem kredit berbasis kelompok (group lending) dengan skema pembiayaan joint liability lending diantaranya mengurangi masalah adverse selection, dimana pada saat pembentukan kelompok memperhatikan mengenai 
kelayakan kredit sehingga dapat mencegah kredit yang beresiko tinggi. Selain itu, dapat mengurangi masalah moral hazard, yaitu masing-masing anggota saling mengawasi dan memantau satu lain untuk memastikan bahwa anggota menggunakan dana kredit untuk kegiatan produktif sehingga akan menjamin pembayaran kredit. Anggota diwajibkan untuk saling memantau untuk menjamin akses kredit di masa mendatang. Apabila terdapat anggota yang tidak bersedia membayar pinjaman maka anggota lain dapat mengenakan sanksi sosial dan tekanan dari semua anggota (Zeller dan Simtowe, 2006).

\subsection{Skim Kredit Program Pemerintah}

Keberhasilan UMKM di Indonesia tidak terlepas dari dukungan dan peran pemerintah dalam mendorong penyaluran kredit kepada UMKM. Berdasarkan UMKM dalam website resmi Bank Indonesia (www.bi.go.id), berbagai skim kredit/pembiayaan UMKM diluncurkan oleh pemerintah dikaitkan dengan tugas program pembangunan ekonomi pada sektor-sektor usaha tertentu, misalnya ketahanan pangan, perternakan dan perkebunan. Peran pemerintah dalam skim-kredit UMKM ini adalah pada sisi penyediaan dana APBN untuk subsidi bunga skim kredit tersebut, sedangkan dana kredit/pembiayaan seluruhnya berasal bank-bank yang ditunjuk pemerintah sebagai bank pelaksana. Selain itu pemerintah berperan dalam mempersiapkan UMKM agar dapat dibiayai dengan tersebut, menetapkan kebijakan dan prioritas usaha yang akan menerima kredit, melakukan pembinaan dan pendampingan selama masa kredit, dan memfasilitasi hubungan antara UMKM dengan pihak lain.

Skim kredit program pemerintah yang terkenal di masyarakat yaitu Kredit Usaha Rakyat (KUR) yang diperuntukkan bagi UMKM yang layak mendapatkan fasilitas kredit, namun tidak mempunyai agunan yang cukup untuk persyaratan kredit perbankan. Tujuan akhir diluncurkan program KUR adalah pengentasan kemiskinan dan penyerapan tenaga kerja. Selain KUR, skim kredit program pemerintah yang lainnya yaitu Kredit Ketahanan Pangan dan Energi (KKPE) dan Kredit Usaha Pembibitan Sapi (KUPS). Pemerintah juga melakukan program pembiayaan untuk usaha produktif yaitu Simpan Pinjam khusus Perempuan (SPP) diberikan pada perempuan rumah tangga miskin (Kusmuljono, 2009).

\subsection{Pembiayaan Bagi Pengusaha UMKM Perempuan}

Grameen Bank merupakan salah satu program kredit mikro yang khusus kaum perempuan. Muhammad Yunus sebagai pendiri dan direktur pengelola Grameen Bank berhasil dalam menyalurkan kredit mikro tersebut. Sistem Grameen Bank menggunakan prinsip tanpa surat perjanjian dan tidak ada sanksi sehingga kepercayaan merupakan modal utama dalam pelaksanaannya. Sistem Grameen Bank menerapkan konsep pemberdayaan masyarakat miskin 
dengan memberikan kepercayaan penuh sehingga memiliki tanggung jawab yang kuat untuk menjadi nasabah yang baik. Grameen Bank bertujuan untuk mengentaskan kemiskinan dengan berlandaskan pada pemberdayaan masyarakat miskin khususnya kaum perempuan (Yunus, 2007).

Grameen Bank menerapkan dua hal agar mencapai keberhasilan sebagai dalam program pengentasan kemiskinan yaitu menjangkau orang miskin dan menerapkan kedisiplinan pengembalian kredit dengan membangun sistem "jaminan sosial". Para peminjam adalah perempuan yang tidak punya tanah dan membentuk kelompok lima orang. Dua diantara yang termiskin mendapat pinjaman pertama. Sedangkan sisanya tiga orang baru akan mendapatkan pinjaman setelah dua orang pertama tadi mengembalikan pinjaman tersebut. Metode seperti ini menjadikan anggota kelompok saling membantu apabila ada anggota yang mengalami kesulitan.

Strategi yang diterapkan Grameen Bank yaitu memberikan pinjaman tanpa jaminan dan bunga rendah kepada masyarakat miskin. Selain itu, pembayaran cicilan dilakukan setiap hari agar tidak memberatkan anggota pada saat jatuh tempo. Nasabah Grameen Bank dikhususkan pada kaum perempuan. Hal ini karena pemberian pinjaman kepada kaum perempuan di Bangladesh ternyata memberikan dampak yang sangat besar terhadap peningkatan ekonomi keluarga dibandingkan kepada kaum laki-laki. Pembentukan kelompok dalam pemberian pinjaman juga merupakan faktor keberhasilan program kredit Grameen Bank.

2.5 Program Nasional Pemberdayaan Masyarakat (PNPM) Mandiri Perdesaan

Program Nasional Pemberdayaan Masyarakat (PNPM) Mandiri merupakan program pembangunan berbasis masyarakat atau Community Driven Development (CDD) sebagai upaya pemerintah dalam membangun kemandirian masyarakat dan mendorong percepatan penurunan kemiskinan. PNPM Mandiri merupakan integrasi dan bertujuan untuk mengkoordinasikan program-program penanggulangan kemiskinan yang berbasis pemberdayaan masyarakat yang sudah sedang berjalan. Integrasi dilakukan dengan menggabungkan program yang terbukti efektif, yaitu Program Pengembangan Kecamatan (PPK) di wilayah perdesaan dan Program Penanggulangan Kemiskinan di Perkotaan (P2KP).

PNPM Mandiri Perdesaan mengadopsi sepenuhnya mekanisme dan prosedur Program Pengembangan Kecamatan (PPK) yang telah dilaksanakan tahun 1998-2007. Dalam PNPM Mandiri Perdesaan, seluruh anggota masyarakat didorong untuk terlibat dalam setiap tahapan kegiatan secara partisipatif, mulai dari proses perencanaan, pengambilan keputusan dalam penggunaan dan pengelolaan dana sesuai dengan kebutuhan yang paling prioritas desanya, hingga pada pelaksanaan kegiatan dan pelestariannya. 
Pelaksanaan PNPM Mandiri Perdesaan berada di bawah binaan Direktorat Pemberdayaan Masyarakat dan Desa (PMD) Departemen/Kementrian Dalam Negeri. Program ini didukung dengan pembiayaan yang bersumber dari alokasi Anggaran Pendapatan Belanja Negara (APBN), alokasi Anggaran Pendapatan dan Belanja Daerah (APBD), partisipasi dari Corporante Social Responsibility (CSR), dana hibah, swadaya masyarakat dan pinjaman dari sejumlah lembaga.

\subsection{Prinsip PNPM Mandiri Perdesaan}

Prinsip-prinsip yang diterapkan dalam Program Nasional Pemberdayaan Masyarakat (PNPM) Mandiri Perdesaan yaitu sebagai berikut :

1. Bertumpu pada pembangunan manusia. PNPM Mandiri Perdesaan memiliki prinsip bahwa setiap kegiatan yang dilakukan bertujuan untuk meningkatkan harkat dan martabat manusia seutuhnya.

2. Otonomi. Masyarakat diberi kewenangan secara mandiri untuk berpartisipasi dalam menentukan dan mengelola kegiatan pembangunan secara mandiri.

3. Desentralisasi. PNPM Mandiri Perdesaan memberikan kewenangan pengelolaan kegiatan pembangunan sektoral dan mengenai kewilayahan dilimpahkan kepada Pemerintah Daerah atau masyarakat sesuai dengan kapasitasnya.

4. Berorientasi pada masyarakat miskin. Semua kegiatan yang dilakukan harus mengutamakan kepentingan dan kebutuhan masyarakat miskin serta kelompok masyarakat yang kurang beruntung.

5. Partisipasi atau keterlibatan masyarakat. masyarakat terlibat secara aktif dalam setiap proses pengambilan keputusan prencanaan, pemantauan, dan pelaksanaan pembangunan serta secara gotong royong melaksanakan pembangunan.

6. Kesetaraan dan Keadilan Gender. Laki-laki dan perempuan mempunyai kesetaraan dalam perannya di setiap tahap pembangunan dan dalam menikmati manfaat kegiatan pembangunan secara adil.

7. Demokratis. Setiap pengambilan keputusan pembangunan di dalam semua kegiatan PNPM Mandiri Perdesaan dilakukan secara musyawarah dan mufakat dengan tetap berorientasi pada kepentingan masyarakat miskin.

8. Transparansi dan Akuntabilitas. Masyarakat harus memiliki akses atas segala informasi proses pengambilan keputusan pembangunan, sehingga pengelolaan kegiatan dapat dilaksanakan secara terbuka dan dapat dipertanggungjawabkan, baik secara moral, legal, teknis dan administratif.

9. Prioritas. Pemerintah dan masyarakat harus memprioritaskan untuk pengentasan kemiskinan, kegiatan mendesak, dan yang memberikan manfaat sebanyak-banyaknya kepada masyarakat dengan mendayagunakan secara optimal berbagai sumber daya yang terbatas. 
10. Kolaborasi. Semua pihak yang berkepentingan dalam penanggulangan kemiskinan diarahkan untuk mewujudkan kerjasama dan sinergi antar pelaku kepentingan dalam penanggulangan kemiskinan.

11. Keberlanjutan. Setiap pengambilan keputusan pembangunan harus mempertimbangkan kepentingan peningkatan kesejahteraan masyarakat, yang tidak hanya untuk saat ini tetapi juga di masa depan dengan tetap menjaga kelestarian lingkungan.

\subsection{Konsep Perguliran Dana Simpan Pinjam Perempuan (SPP)}

Tingkat keberdayaan kaum perempuan harus dipertimbangkan dalam upaya mensejahterakan masyarakat secara keseluruhan (Suman, 2007). Hal ini disebabkan karena kaum perempuan dari sudut pandang budaya lokal dalam masyarakat pertanian, lebih banyak tinggal di rumah dan memiliki banyak waktu luang. Keterlibatan perempuan di dalam sektor pertanian hanya pada waktu tertentu, yaitu seperti masa tanam dan masa panen.

Simpan Pinjam Perempuan (SPP) merupakan salah satu kegiatan program PNPM Mandiri Perdesaan yang berupa kegiatan perguliran dana untuk menjadikan masyarakat miskin perdesaan khususnya kaum perempuan lebih berdaya. Pemberdayaan yang dimaksud merupakan ketersediaan pilihan bagi masyarakat miskin untuk memanfaatkan peluang usaha sehingga mendapatkan tambahan pendapatan. Pengambilan keputusan untuk menentukan jumlah alokasi untuk SPP dikendalai oleh jumlah alokasi dana untuk pembangunan sarana / prasarana. Semakin besar proporsi dana untuk fasilitas sarana dan prasarana, maka semakin kecil ketersediaan dana untuk kegiatan SPP. Sedangkan keputusan pembiayaan kegiatan SPP ditentukan oleh kelayakan proposal yang diajukan oleh kelompok SPP.

Pengorganisasian kelompok SPP dapat dilakukan dengan memanfaatkan organisasi-organisasi lokal baik formal maupu informal yang sudah ada dalam lingkungan masyarakat, seperti kelompok dasa wisma atau kelompok pengajian. Kelompok SPP dapat mengakses dana untuk usaha produktif maupun untuk keperluan keluarga, seperti untuk biaya pendidikan. Kredit yang disalurkan kepada kelompok diharapkan menjadi penggerak aktivitasaktivitas produktif mampu memberikan nilai tambah bagi anggota kelompok. Kredit berkelompok memiliki akses yang relatif lebih besar dibandingkan kredit individu karena berkaitan dengan besarnya posisi tawar kelompok (Ismawan, 2001). Penyaluran kredit kepada pelaku UMKM secara kelompok merupakan salah satu untuk mengurangi kesalahan penggunaan dana kredit (moral hazard) dan mengurangi resiko kredit bermasalah.

2.8 Konsep Pemberdayaan Masyarakat

Pemberdayaan berasal dari bahasa Inggris yaitu empowerment. 
Pemberdayaan merupakan suatu pendekatan yang berorientasi pada manusia dengan mengedepankan asas partisipasi. Menurut Kusmuljono (2009) Pemberdayaan masyarakat mengandung makna mengembangkan, memandirikan, menswadayakan, dan memperkuat bargaining position masyarakat lapisan bawah terhadap kekuatan penekan di segala bidang kehidupan. memberdayakan masyarakat adalah upaya untuk meningkatkan harkat dan martabat lapisan masyarakat yang tidak mampu melalui pengembangan kemampuan masyarakat memiliki keterampilan dalam mengatasi masalah. Pemberdayaan masyarakat dapat dilakukan melalui pengembangan kelembagaan masyarakat dan sinkronisasi antara pendampingan, penyuluhan dan pelayanan.

Pemberdayaan masyarakat mengacu pada kemampuan masyarakat untuk mendapatkan dan memanfaatkan akses atas sumber daya yang penting. Masyarakat miskin dianggap berdaya apabila mampu meningkatkan kesejahteraan sosial-ekonominya melalui peningkatan kualitas sumber daya manusia (SDM), peningkatan kemampuan permodalan, dan pengembangan usaha. Sedangkan partisipasi merupakan proses aktif dimana masyarakat miskin relatif lebih diuntungkan oleh keberlangsungan proyek pembangunan (Ismawan, 2001).

Pendekataan utama dalam konsep pemberdayaan masyarakat adalah bahwa masyarakat tidak dijadikan objek dari berbagai proyek pembangunan, tetapi menjadi subjek dari upaya pembangunan. Berdasarkan konsep tersebut dikembangkan berbagai pendekatan :

1. Upaya pemberdayaan masyarakat harus terarah. Program yang dijalankan harus langsung mengikutsertakan masyarakat yang menjadi sasaran, sehingga bantuan tersebut efektif karena sesuai dengan kemampuan dan kebutuhan masyarakat.

2. Menggunakan pendekatan kelompok karena secara sendiri-sendiri masyarakat yang kurang berdaya sulit untuk memcahkan masalah yang dihadapinya. Selain itu, pendekatan kelompok juga lebih efisien dilihat dari sumber penggunaan sumberdaya.

3. Adanya pendampingan, karena penduduk miskin umumnya mempunyai keterbatasan dalam mengembangkan dirinya. Oleh karena itu, diperlukan pendamping untuk membimbing dalam upaya memperbaiki kesejahteraannya. Pendampingan dalam konsep pemberdayaan berfungsi membantu mencari solusi pemecahan masalah yang tidak dapat dilakukan oleh masyarakat itu sendiri.

\section{Hasil Penelitian}

\section{Sekilas UPK-PNPM Kecamatan Samatiga}

Berbagai macam persiapan dan perencanaan secara matang telah dilakukan Unit Pengelola Kegiatan (UPK) Kecamatan Samatiga dalam 
melaksanakan Simpan Pinjam khusus Perempuan (SPP) berbasis Sistim Syariah. Kegiatan ini juga telah melibatkan pemerintah lokal, cendikiawan dan alim ulama. Demi memudahkan kinerja, maka dirumuskan visi dan misi sebagai acuannya. Selain Visi dan Misi UPK juga telah mempedomani standar operasional prosedur (SOP) dalam menjalankan tugasnya sehari-hari. Dengan kinerja dan semangat tinggi UPK Kecamatan Samatiga telah mampu mengembangkan dana guliran kepada masyarakat. Namun tidak semua warga masyarakat bias mendapatkan guliran dana SPP, kecuali yang memenuhi persyaratan menjadi kelompok sebagai berikut:

\section{A. Persyaratan}

Persyaratan kelompok yang akan mengajukan Simpan Pinjam khusus Perempuan (SPP), mengacu pada Standar Operasional Prosedur (SOP) UPKPNPM Perdesaan Kecamatan Samatiga.

1. Kelompok SPP yang mempunyai ikatan pemersatu yang kuat, misalnya Rukun Tetangga/Rukun Warga, Dasa Wisma, PKK, Arisan, Tahlilan, Yasinan dan lain sebagainya.

2. Mempunyai kepengurusan yang jelas minimal Ketua, Sekretaris dan Bendahara.

3. Mempunyai kegiatan ekonomi dan atau kemasyarakatan.

4. Anggota kelompok yang menjadi pemanfaat pinjaman perguliran adalah benar-benar warga desa setempat dibuktikan dengan foto kopi KTP dan atau Kartu KK yang dilegalisir oleh pemerintah desa setempat serta surat keterangan dari RT dan atau RW setempat.

5. Anggota kelompok peminjam wajib mendapatkan persetujuan tertulis dari salah satu anggota keluarganya (suami atau orang tua).

6. Kelompok peminjam :

a. Kelompok penyalur pinjaman (chanelling) dengan persyaratan tambahan :

(1). Minimal berumur 1 tahun.

(2). Minimal mempunyai buku notulen dan atau buku kas harian.

(3). Minimal mempunyai kegiatan rutin, minimal ada pertemuan bulanan.

(4). Anggota kelompok yang meminjam maksimal $100 \%$ Anggota.

(5). Dalam satu kelompok yang meminjam tidak boleh terdiri ibu, anak dan anggota keluarga lainnya yang masuk dalam 1 (satu) Kartu KK.

b. Kelompok pengelola pinjaman (executting) dengan persyaratan. tambahan :

(1). Minimal, berumur 3 tahun.

(2). Mempunyai pengalaman mengelola dana simpanan dan pinjaman 
minimal 2 tahun.

(3). Mempunyai Anggaran Dasar/Anggaran Rumah Tangga secara tertulis.

(4). Pernah mendapat pinjaman dari UPK minimal 2 kali dengan pembayaran angsuran kategori lancar.

(5). Mempunyai aturan pengelolaan dana simpanan dan pinjaman mencakup jenis-jenis simpanan, bunga simpanan, persyaratan pinjaman, jumlah pinjaman, jangka waktu, sanksi secara tertulis.

c. Kelompok penyalur pinjaman (chanelling) yang mengajukan pinjaman perguliran wajib mempunyai tabungan kelompok sebesar $10 \%$ dari besaran pengajuan pinjaman, selanjutnya tabungan tersebut sebagai agunan tanggung renteng.

7. Kelompok pengelola pinjaman (executing) yang mengajukan pinjaman perguliran wajib mempunyai tabungan kelompok sebesar 20\% dari besaran pengajuan pinjaman, selanjutnya tabungan tersebut sebagai agunan tanggung renteng.

8. Kelompok pengelola pinjaman (executing) dapat mengajukan pinjaman maksimal sebesar 300\% dari tabungan kelompok dan modal kelompok.

\section{B. PROSEDUR PERMOHONAN PINJAMAN PERGULIRAN}

1. Mengadakan pertemuan kelompok untuk menentukan anggota kelompok yang menjadi pemanfaat pinjaman perguliran, dengan bukti daftar hadir dan berita acara pertemuan.

2. Menentukan jumlah angsuran, jadwal angsuran, sedangkan untuk kelompok pengelola pinjaman (chanelling) ditambahkan ketentuan penentuan tingkat bunga dan penentuan persyaratan pinjaman.

3. Proposal/permohonan pinjaman perguliran diserahkan ke UPK.

4. Anggota kelompok yang kelompoknya masih mempunyai pinjaman dari UPK, maka anggota kelompok tersebut tidak dapat membentuk kelompok baru untuk mengajukan pinjaman.

\section{Group Lending Kelompok SPP di Samatiga}

Kesuksesan kelompok-kelompok SPP di Kecamatan Samatiga salah satunya adalah persyaratan yang dikembangkan sendiri oleh kelompok. Persyaratan nomor 5 (lima) yang diminta UPK yakni harus mendapatkan persetujuan suami, persyaratan ini dikembangkan menjadi selain persetujuan suami atau keluarga juga harus memberikan boroh atau jaminan dalam bentuk apa saja. Selain memberikan jaminan berupa boroh, masyarakat yang bergabung ke dalam kelompok sudah melakukan seleksi siapa saja yang boleh menjadi anggota kelompok. Hal ini jelas bukan ketentuan dari UPK PNPM, namun inisiator pembentuk kelompok sendiri yang menentukan agar di 
kemudian hari kelompoknya tidak mendapat sanksi yang menurut anggota kelompok sanksi itu dipandang sangat memalukan. Boroh sebenarnya tidak diperlukan dalam program ini, karena meminta boroh akan sama saja dengan menutup masyarakat tidak mampu dalam mengakses sumber keuangan untuk modal usaha. Namun, boroh yang dijaminkan kepada kelompok oleh anggotanya resiko yang ditanggung tidak seberat jika dijaminkan kepada sumber keuangan seperti bank.

Selain boroh, kelompok juga menghimpun dana kas tersendiri. Konsepnya setiap membayar angsuran kepada bendahara, anggota wajib menyetor dana lebih. Sebelumnya pengurus kelompok menghitung antara dana yang harus disetor kelompok ke UPK PNPM dan jumlah yang harus menjadi dana kas kelompok. Dengan dana kas ini kelompok dapat berperan membantu seorang anggota yang sedang kesulitan membayar setoran. Dana kas ini dihimpun dari anggota kelompok sepanjang satu tahun (masa pinjaman), sehingga dalam kondisi tertentu dana kas kelompok benar-benar dapat dimanfaatkan untuk membantu anggota yang sedang kesulitan membayar angsuran, dan dapat dibagikan kembali jika anggota memutuskan keluar dari kelompok ketika masa pinjamannya telah diselesaikan.

\section{Dana Guliran Kelompok SPP dan Keuntungan}

UPK Kecamatan Samatiga selama tahun 2013, telah menggulirkan dana untuk simpan pinjam khusus perempuan (SPP) sebesar Rp. 2.520.000.000,- (dua miliar lima ratus dua puluh juta rupiah). Jumlah ini hanya $88 \%$ dari seluruh dana yang direncanakan sebelumnya, dana yang direncanakan untuk guliran SPP tahun 2013 adalah sejumlah Rp. 2.869.000.000,- (dua miliar delapan ratus enam puluh sembilan juta rupiah). Dana guliran dari UPK yang diserap kelompok SPP di Kecamatan Samatiga memberikan keuntungan tersendiri bagi UPK, bahkan keuntungan itu selalu mengalami kenaikan setiap tahunnya. Keuntungan yang diterima UPK pada tahun 2011 sejumlah Rp. 59.138.060 (lima puluh sembilan juta seratus tiga puluh delapan ribu enam puluh rupiah), mengalami peningkatan sejumlah 78,58\% (tujuh puluh delapan koma lima puluh delapan persen) menjadi Rp. 105.609.070 (seratus lima juta enam ratus sembilan ribu tujuh puluh rupiah) pada tahun 2012. Sedangkan pada tahun 2013, juga mengalami peningkatan keuntungan menjadi Rp. 146.194 .339 (seratus empat puluh enam juta seratus sembilan puluh empat ribu tiga ratus tiga puluh sembilan rupiah), atau meningkat sebesar 38,43\% (tiga puluh delapan koma empat puluh tiga persen). 
Community: Volume 3, Nomor 1, April 2017

ISSN: 2477-5746

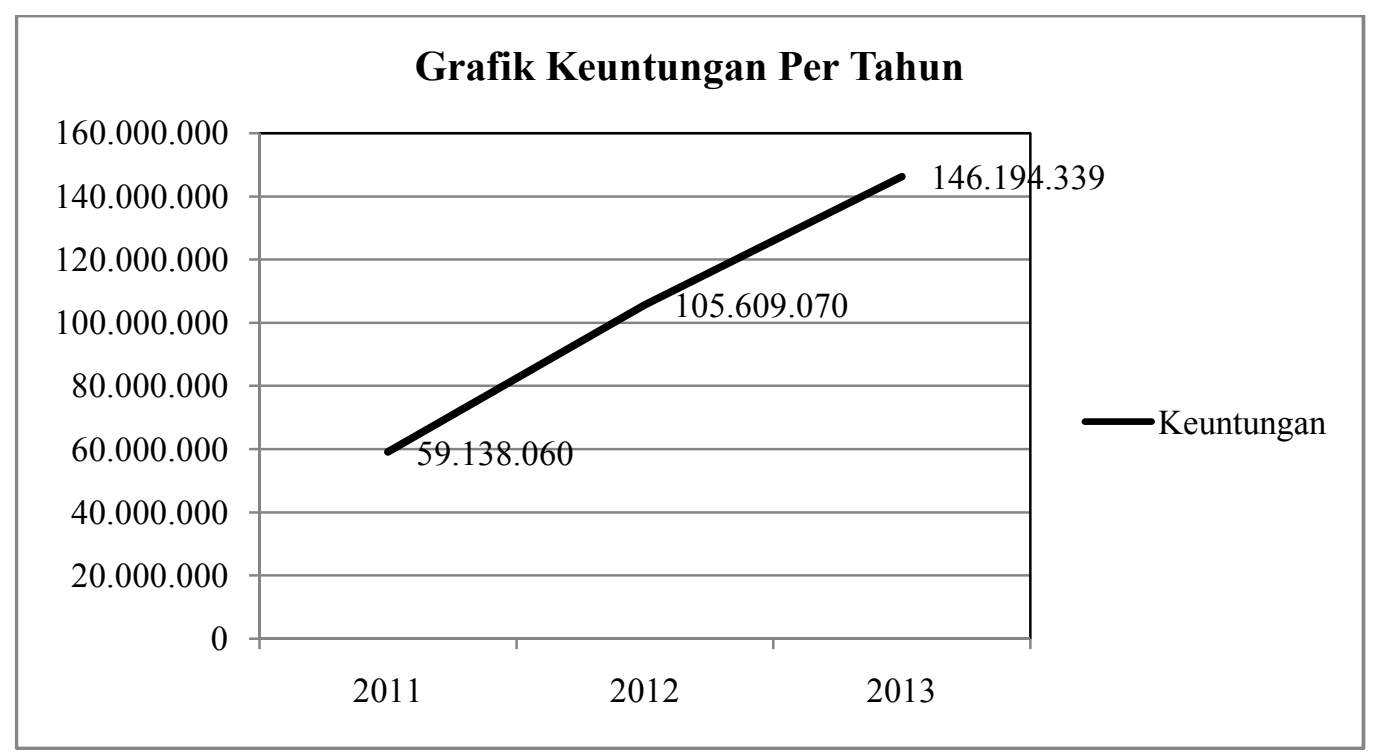

Sumber: Laporan UPK Kecamatan Samatiga

\section{Gambar 1. Grafik Keuntungan Dana Guliran}

Pada tahun 2014 ini UPK telah menetapkan target keuntungan yang lebih besar lagi, yakni sejumlah Rp. 250.369.888,- (dua ratus lima puluh juta tiga ratus enam puluh sembilan ribu delapan ratus delapan puluh delapan rupiah). Untuk mencapai target tersebut UPK merencanakan menyediakan dana sebesar Rp. 3.520.000.000,- (tiga milyar lima ratus dua puluh juta rupiah), sebagai dana guliran SPP. Dilihat dari besarnya keuntungan yang diterima, menunjukkan keberhasilan program SPP yang dikelola oleh UPK Kecamatan Samatiga. Keuntungan tersebut mengindikasikan adanya proses pengembalian yang stabil dan terkontrol. Asumsinya adalah jika pengembalian tidak stabil dan terkontrol oleh UPK, maka keuntungan yang diperoleh tidak akan signifikan. Akan tetapi, pengembalian yang rutin dan terkontrol akan meningkatkan modal dana guliran SPP, karena pengembalian disertai dengan bunga sebesar $1 \%$ per bulan atau $12 \%$ per tahun.

\section{Perkembangan UMKM}

Kaum perempuan khususnya ibu-ibu di perdesaan memiliki waktu luang yang cukup banyak. Hal ini disebabkan karena kaum perempuan dari sudut pandang budaya lokal dalam masyarakat pertanian, lebih banyak tinggal di rumah dan memiliki banyak waktu luang. Keterlibatan perempuan di dalam sektor pertanian hanya pada waktu tertentu, yaitu seperti masa tanam dan masa panen. Selain waktu-waktu tersebut, perempuan di pedesaan tidak bekerja, sehingga tidak menambah penghasilan bagi keluarganya. Kondisi seperti ini dilihat PNPM Mandiri Perdesaan untuk memberdayakan melalui Simpan Pinjam Perempuan (SPP). SPP ini merupakan kegiatan perguliran dana 
untuk menjadikan masyarakat miskin perdesaan khususnya kaum perempuan lebih berdaya. Pemberdayaan yang dimaksud merupakan ketersediaan pilihan bagi masyarakat miskin untuk memanfaatkan waktu luang dan peluang usaha yang ada di lingkungannya sehingga dapat menambah penghasilan keluarga.

Dengan program SPP ini tenaga perempuan di perdesaan akan termanfaatkan dan menjadi produktif. Artinya, dengan program SPP ini mampu membuka usaha-usaha baru skala kecil di tingkat perdesaan. Guliran dana SPP dari UPK Kecamatan Samatiga secara tidak langsung telah mampu membangun UMKM di gampong-gampong di wilayah Kecamatan Samatiga. Data penelitian menunjukkan pada tahun 2013 telah terbentuk 56 (lima puluh enam) kelompok pengusul program SPP, di mana pengusul kelompokkelompok ini telah membuat perencanaan usaha sesuai kemampuan dan keterampilannya masing-masing. Program SPP secara nyata mampu merangsang masyarakat untuk melakukan usaha meskipun hanya kecilkecilan. Sebagaimana diketahui bahwa usaha mikro, kecil dan menengah telah memberikan kontribusi yang tinggi dalam meningkatkan pertumbuhan ekonomi nasional. Data BPS tahun 2011, UMKM mampu menyumbangkan pendapatan (PDB) sebesar 1369326.00 (dalam satuan miliar), atau menyumbangkan pertumbuhan sumbangan PDB sebesar 6,76 persen. Sedangkan data sementara BPS sumbangan PDB sektor UMKM sebesar 1504928,2 (dalam satuan miliar), atau menyumbangkan pertumbuhan PDB sebesar 9,90 persen (http:/ / www.bps.go.id/).

Hasil amatan di lapangan menunjukkan, bahwa dana dari program pemberdayaan SPP UPK-PNPM Perdesaan di Kecamatan Samatiga mampu memunculkan kelompok-kelompok pengusaha kecil di masyarakat. Data UPKPNPM Kecamatan Samatiga juga menunjukkan adanya peningkatan dana guliran dan peningkatan keuntungan dari tahun ke tahun (LPJ UPK Samatiga 2013). Kemunculan kelompok usaha tersebut, berdasarkan laporan keuntungan dari guliran dana SPP sangat jelas menunjukkan adanya peningkatan aset UPK, dan itu menunjukkan adanya pertumbuhan PDB nasional.

Kelompok Sabe Pakat dan Sinar Bahari dari Gampong Kuala Bubon, menekuni usaha pembuatan ikan asin yang sempat dipasarkan sampai ke Kuala Bhee yancg merupakan ibu kota Kecamatan Woyla Induk. Gampong Kula Bubon merupakan daerah pesisir, sehingga mayoritas masyarakatnya memiliki mata pencaharian sebagai nelayan. Ketika para lelaki pergi melaut, kaum ibu atau perempuan memanfaatkan waktunya untuk membuat ikan asin agar bisa meningkatkan penghasilan keluarga.

Kelompok-kelompok dari Gampong Suak Gedubang, seperti Usaha Tamita, walaupun gampong di daerah pesisir, namun memiliki pemandangan pantai yang indah, sehingga oleh masyarakat dijadikan sebagai obyek pariwisata lokal. Kondisi ini membuat warganya berinisiatif untuk membuka 
tempat peristirahatan untuk menikmati indahnya pemandangan. Tempat wisata local/peristirahatan ini juga menyediakan berbagai macam menu minuman dan makanan. Untuk menopang usahanya, kelompok-kelompok SPP dari gampong ini memanfaatkan layanan SPP dari UPK Kecamatan Samatiga.

\section{Penyerapan Tenaga Kerja}

Kelompok-kelompok SPP serupa juga berdiri di gampong-gampong lainnya yang mencoba memanfaatkan potensi desanya masing-masing. Jika satu kelompok terdiri dari 10 (sepuluh) orang, dan semua anggota kelompok terlibat dalam usaha yang dibangun, maka 56 kelompok yang tersebar di seluruh Kecamatan Samatiga akan menyerap tenaga kerja sejumlah 560 (lima ratus enam puluh) orang. Angka tersebut belum termasuk jumlah tenaga kerja yang diperlukan oleh masing-masing tempat usaha. Sebagai contoh, kelompok Usaha Tamita yang terdiri dari 10 anggota. Masing-masing anggota memiliki tempat usaha berupa warung makanan dan minuman, pemilik warung ini tidak bisa bekerja sendirian di tempat usahanya yang rata-rata luasnya kurang lebih 15 × 50 meter. Untuk itu, anggota kelompok akan merekrut tenaga kerja baik dari lingkungan keluarga maupun dari orang lain. Jika diasumsikan masing-masing merekrut 2 orang tenaga kerja, maka total tenaga kerja terserap kurang lebih $560 \times 2$ tenaga kerja $=1.120$ orang. Hal ini selaras dengan data BPS, bahwa pertumbuhan UMKM pada tahun 2010 sampai dengan 2012, juga diikuti dengan laju pertumbuhan tenaga kerja. Tahun 2010 tercatat bahwa jumlah tenaga kerja UMKM sejumlah 99.401 .775 orang, dan jumlah ini semakin meningkat hingga tahun 2012 tercatat jumlah tenaga kerja UMKM sejumlah 107.657.509 orang (http://www.bps.go.id/).

\section{Pendampingan}

Dalam membantu mensukseskan kelompok-kelompok yang mengajukan SPP, sekaligus menjaga agar dana digunakan sesuai dengan kebutuhan, UPK Kecamatan Samatiga telah memberikan bantuan dalam bentuk pendampingan. Pendampingan yang dilakukan khusus pada pengelolaan atau manajemen keuangan, pengarsipan dan pelaporan. Untuk itu, dengan kerjasama pelaku PNPM lainnya di tingkat kecamatan, UPK melakukan pelatihan-pelatihan sebagai berikut:

a. Pelatihan Tim Penulis Usulan (TPU) gampong tahun 2014.

b. Pelatihan Tim verifikasi usulan kegiatan tahun 2014.

c. Pelatihan Tim monitoring.

d. Pelatihan tim pemeliharaan.

e. Pelatihan aparatur gampong.

Selain pelatihan yang dilakukan untuk meningkatkan kemampuan kelompok-kelompok masyarakat, UPK juga meningkatkan kemampuan petugas agar lebih terampil dalam membantu dan memberikan layanan kepada 
masyarakat. Berdasarkan beberapa program pendampingan yang dilakukan UPK, tampak bahwa sejauh ini pendampingan hanya sebatas pada pengelolaan administrasi kelompok-kelompok SPP. Hal ini dapat dipahami karena keberhasilan kelompok ditunjukkan dengan rutinitas kelompok melakukan setoran kepada UPK, sehingga pada waktu yang ditentukan total pinjaman kelompok dapat terbayar lunas.

Pengelola dana guliran SPP belum mampu memberikan pendampingan kepada anggota kelompok dalam pengelolaan usaha. Tentu akan sangat bermanfaat apabila UPK memberikan dampingan kepada anggota kelompok yang melakukan usaha, karena dampingan ini akan memperbesar peluang anggota kelompok menuju kesuksesan usaha yang berujung pada bukan hanya lancar dalam membayar setoran tetapi juga keberlangsungan usaha masyarakat. Ketidakmampuan UPK dalam pendampingan mengelola usaha yang dilakukan anggota kelompok SPP disebabkan ketiadaan sumber daya manusia yang memiliki keahlian dalam pengelolaan usaha. Solusinya UPK harus mendatangkan tenaga ahli untuk mendampingi masyarakat dalam menjalankan dan mengembangkan usaha anggota kelompok SPP, dan sejauh ini belum pernah dilakukan.

\section{Hasil Uji Statistik}

Untuk melihat dampak atau pengaruh guliran dana simpan pinjam khusus untuk perempuan (SPP) terhadap tenaga kerja dan UMKM juga dilakukan melalui uji statistik. Dalam penelitian ini digunakan software SPSS 11.5 untuk menganalisis ada atau tidaknya dampak guliran dana SPP. Berdasarkan data yang dikumpulkan melalui kuisioner, dapat dilakukan uji validitas dan realibilitas terlebih dahulu, sebagaimana berikut ini:

\section{Pengujian Validitas dan Realibilitas Variabel X (guliran dana SPP)}

Pada variabel $X$ yang merupakan variabel bebas (independent), atau variabel yang mempengaruhi variabel-variabel lainnya. Variabel ini dibuat dalam beberapa pertanyaan untuk memperjelas guliran dana simpan pinjam khusus untuk perempuan. Pertanyaan tersebut merupakan pertanyaan tertutup, dimana jawaban dibatasi dengan skala linkert, yakni 1. Sangat Tidak Setuju, 2. Tidak Setuju, 3. Kurang Setuju, 4. Setuju, dan 5. Sangat Setuju. Uji validitas variable $X$ terjadi tiga kali untuk mendapatkan data yang valid, di mana $R$ tabel yang didapatkan berturut-turut 0,388 pada uji validitas pertama, 0,381 pada uji validitas kedua, dan 0,374 pada uji validitas ke tiga.

Berdasarkan uji validitas yang ketiga tersebut, semua nilai pada kolom Corrected Item-Total Correlation menunjukkan nilai yang lebih besar dari Rtabel yakni dengan nilai $\mathrm{df}=30-4=26$, tampak Rtabel bernilai 0,374, dan semua pertanyaan valid. Sementara itu, pada uji realibilitas ditunjukkan dengan nilai 
alpha cronbach pada uji validitas yang sudah valid. Data valid semua ditunjukkan pada pengujian ketiga, dan muncul nilai alpha cronbach's adalah 0,7551. Angka tersebut lebih besar dari 0,60, sehingga disebut realibel.

Suatu data dapat disebut realibel etika nilainya Alpha Cronbach's $>0,60$. Berdasarkan tabel di atas maka dapat dipastikan bahwa data variabel $\mathrm{X}$ telah realibel, karena alpha cronbach's menunjukkan angka 0,7551, dan berarti lebih besar dari 0,60.

\section{Uji Validitas dan Reabilitas Pada Variabel Terikat (Y1)}

Uji validitas juga dilakukan pada variabel tergantung (Y1) yakni tentang penyerapan tenaga kerja. Hal ini dilakukan untuk mengetahui pengaruh guliran dana SPP terhadap tenaga kerja atau kebutuhan tenaga kerja akibat kemunculan usaha yang dilakukan ibu-ibu anggota kelompok. Dengan demikian juga dapat dikatakan apakah guliran dana SPP tersebut bermanfaat untuk pengurangan angka pengangguran di Kecamatan Samatiga atau tidak.

Setelah semua data pertanyaan yang mengarah pada tenaga kerja dianalisis dengan SPSS 11.5, maka data yang diperoleh menunjukkan bahwa semua pertanyaan valid, karena Corrected Item-Total Correlation atau Rhitung lebih tinggi dari pada Rtabel. Rtabel dapat dilihat pada baris ( $\mathrm{df}=30-7)$ ke 23, di mana menunjukkan angka 0,367. Sedangkan dalam tabel realiability statistik juga sudah realibel karena nilai alpha cronbach menunjukkan 0,7872 dan lebih besar dari alpha cronbach 0,60. Artinya uji validitas pada variabel Y1 ini dapat dilakukan hanya satu kali pengujian saja.

\section{Uji Validitas dan Reabilitas Pada Variabel Terikat (Y2)}

Hasil uji validitas pada variabel terikat ke dua (Y2) yakni tentang pengaruh guliran dana SPP terhadap perkembangan UMKM juga menunjukkan angka nilai yang serupa dengan variabel terikat pertama, artinya semua pertanyaan menunjukkan valid, dengan $R$ table 0,374 , sedangkan $R$ hitung paling rendah adalah 0,4354 . Sementara itu dalam tabel realiability nilainya tampak realibel, hal ini ditunjukkan dengan nilai alpha cronbach sebesar 0,8142. Pada uji validitas variabel terikat Y2 ini juga hanya dilakukan sekali pengujian saja.

\section{Uji Regresi Linear}

Hasil penghitungan SPSS menunjukan koefisien determinasi, dengan adjusted R Square sebesar 0,637 yang berarti guliran dana SPP berpengaruh terhadap tenaga kerja sebesar $63,7 \%$, sedangkan sisanya dipengaruhi faktor lainnya. 
Tabel 3: Koefisien determinasi Pengaruh Guliran Dana SPP Terhadap Tenaga Kerja

Model Summary(b)

\begin{tabular}{|r|r|r|r|r|}
\hline Model & $\mathrm{R}$ & \multicolumn{1}{|c|}{ R Square } & Adjusted R Square & Std. Error of the Estimate \\
\hline 1 & $.806(\mathrm{a})$ & .650 & .637 & 15.10486 \\
\hline
\end{tabular}

a Predictors: (Constant), JMLX

$b$ Dependent Variable: JMLY1

Sementara itu koefisien determinasi yang ditunjukkan analisis SPSS pada pengaruh guliran dana SPP terhadap perkembangan UMKM adalah sebesar $65,1 \%$ dan sisanya ditentukan faktor lain, hal ini ditunjukkan dengan nilai Adjusted R Square sebesar 0,651.

Tabel 4: Koefisien determinasi Pengaruh Guliran Dana SPP Terhadap Perkembangan UMKM

Model Summary(b)

\begin{tabular}{|r|c|r|r|r|}
\hline Model & $\mathrm{R}$ & R Square & Adjusted R Square & Std. Error of the Estimate \\
\hline 1 & $.814(\mathrm{a})$ & .663 & .651 & 18.96693 \\
\hline
\end{tabular}

a Predictors: (Constant), JMLX

b Dependent Variable: JMLY2

Dalam tabel Koefisien juga menunjukkan adanya dampak atau pengaruh guliran dana SPP terhadap tenaga kerja dan pengaruhnya terhadap perkembangan UMKM. Lebih jelas dapat dilihat tabel koefisien berikut:

Tabel 5: Tabel Koefisien Pengaruh Dana Guliran SPP Terhadap Tenaga Kerja

Coefficients(a)

\begin{tabular}{|c|c|c|c|c|c|c|}
\hline \multirow[t]{2}{*}{ Model } & & \multicolumn{2}{|c|}{$\begin{array}{l}\text { Unstandardized } \\
\text { Coefficients }\end{array}$} & \multirow{2}{*}{$\frac{\text { Standardized Coefficients }}{\text { Beta }}$} & \multirow[t]{2}{*}{$\mathrm{t}$} & \multirow[t]{2}{*}{ Sig. } \\
\hline & & B & Std. Error & & & \\
\hline 1 & (Constant) & 17.414 & 18.594 & & .937 & .357 \\
\hline & JMLX & .663 & .092 & .806 & 7.210 & .000 \\
\hline
\end{tabular}

a Dependent Variable: JMLY1

Tabel 6: Tabel Koefisien Pengaruh Dana Guliran SPP Terhadap UMKM

Coefficients(a)

\begin{tabular}{|c|c|c|c|c|c|c|}
\hline \multirow[t]{2}{*}{ Model } & & \multicolumn{2}{|c|}{$\begin{array}{c}\text { Unstandardized } \\
\text { Coefficients }\end{array}$} & \multirow{2}{*}{$\begin{array}{c}\begin{array}{c}\text { Standardized } \\
\text { Coefficients }\end{array} \\
\text { Beta } \\
\end{array}$} & \multirow[t]{2}{*}{ t } & \multirow[t]{2}{*}{ Sig. } \\
\hline & & $B$ & Std. Error & & & \\
\hline 1 & (Constant) & 28.686 & 23.348 & & 1.229 & .229 \\
\hline & JMLX & .857 & .115 & .814 & 7.419 & .000 \\
\hline
\end{tabular}

a Dependent Variable: JMLY2 
Rumusan asumsinya adalah:

$\mathrm{H}_{0}$ : Tidak ada dampak atau pengaruh guliran dana SPP terhadap Tenaga Kerja

$\mathrm{H}_{1}$ : Ada pengaruh atau dampak guliran dana SPP terhadap Tenaga Kerja

dan

$\mathrm{H}_{0}$ : Tidak ada dampak atau pengaruh guliran dana SPP terhadap perkembangan UMKM

$\mathrm{H}_{2}$ : Ada pengaruh atau dampak guliran dana SPP terhadap perkembangan UMKM.

Tabel-tabel coefficients di atas menunjukkan $\mathrm{T}$ atau uji parsial, nilai sig pada jumlahx sebesar 0,000. Karena sig lebih kecil dari 0,05 maka $\mathrm{H}_{0}$ ditolak dan $\mathrm{H}_{1}$ diterima. Dengan demikian maka guliran dana SPP berpengaruh pada tenaga kerja dan berpengaruh pada perkembangan UMKM.

\section{KESIMPULAN DAN SARAN \\ Kesimpulan}

Kesimpulan yang dapat diambil adalah bahwa;

1. Keragaan penyaluran pinjaman bergulir program SPP bagi UMKM di Kecamatan Samatiga dilakukan melalui kelompok-kelompok sebagai pengusul program SPP, yang telah memenuhi persyaratan-persyaratan tertentu yang telah ditetapkan oleh UPK.

2. Guliran dana SPP PNPM Mandiri Perdesaan memiliki dampak terhadap penyerapan tenaga kerja dan perkembangan UMKM di Kecamatan Samatiga. Terbukti dengan munculnya lapangan kerja baru yang mampu menyerap tenaga kerja khususnya perempuan di pedesaan, bahkan mampu meningkatkan ekonomi rumah tangga bukan hanya anggota kelompok tetapi juga orang-orang yang direkrut sebagai tenaga kerja. Dampak atau pengaruh guliran dana SPP terhadap tenaga kerja dan perkembangan UMKM ini ditunjukkan dengan tabel koefisien di mana nilai sig lebih kecil dari 0,05 maka $\mathrm{H}_{0}$ ditolak dan $\mathrm{H}_{1}$ diterima. Dengan demikian maka guliran dana SPP berpengaruh pada tenaga kerja dan perkembangan UMKM.

\section{Saran}

Berdasarkan hasil kajian sementara, maka dapat diberikan saran kepada UPK:

1. Agar diberikan pendampingan mengenai keterampilan yang berkaitan dengan keahlian dalam bidang usaha yang ditekuni oleh masyarakat. Selama ini UPK baru sebatas memberikan pendampingan mengenai 
sistem pembukuan administrasi yang baik, dan belum mengarah kepada keterampilan usaha.

2. UPK tidak memerlukan syarat berupa anggunan, tetapi syarat keanggotaan kelompok harus menyerahkan boroh/anggunan, sebaiknya dikembalikan sesuai dengan ketentuan yang berlaku. Karena dengan syarat anggota kelompok harus menyerahkan boroh, akan menghambat masyarakat yang tidak memiliki jaminan untuk menjadi anggota kelompok SPP.

\section{PUSTAKA}

Ismawan, Indra. 2001. Sukses Di Era Ekonomi Liberal Bagi Koperasi dan Perusahaan Kecil-Menengah. Grasindo : Jakarta.

Juanda, Bambang. 2009. Metodologi Penelitian Ekonomi dan Bisnis. IPB Press: Bogor.

Kusmuljono, B.S. 2009. Menciptakan Kesempatan Rakyat Berusaha: Sebuah Konsep Baru Tentang Hybrid Microfinancing. IPB Press : Bogor.

Simtowe, Franklin dan Zeller, Manfred. 2006. Determinants of Moral Hazard in Microfinance : Empirical Evidence from Joint Liability Lending Programs in Malawi. MPRA Paper No. 461

Suman, Agus. 2007. Pemberdayaan Perempuan, Kredit Mikro, dan Kemiskinan: Sebuah Studi Empiris. Jurnal Manajemen dan Kewirausahaan, Vol. 9, No. 1, hal.62-72.

Suyatno, Thomas, Pramono, Bambang dan Hutapea, Erwin. 2007. Dasar - Dasar Perkreditan. Edisi Keempat. Gramedia Pustaka Utama: Jakarta.

Unit Pengelola Kegiatan Kecamatan Samatiga. 2013. Laporan Pertanggungjawaban UPK tahun 2013 Kecamatan Samatiga Kabupaten Aceh Barat.

Untung, Budi. 2000. Kredit Perbankan di Indonesia. Andi: Yogyakarta.

$\begin{array}{llllll}\text { Tabel Perkembangan } & \text { UMKM } & \text { pada }\end{array}$ (http://www.bps.go.id/)

Yunus, Muhammad. 2007. Bank Kaum Miskin. Marjin Kiri: Depok.

Zeller, Manfred. dan L.M. Richard. 2002. The Triangle of Microfinance: Financial Sustainability, Outreach, and Impact. IFPRI Food Policy Statement. Number 40, November 2002. www.ifpri.org [ 4 Maret 2012] 